\title{
ANALISIS FENOMENA CAMPUR KODE DAN ALIH KODE PADA MEDIA SOSIAL TWITTER Fani Fazrul Hikam ${ }^{1}$, Fickyh Verdhyawan Santoso ${ }^{2}$, Mahdi ${ }^{3}$ \\ Jurusan Sastra Indonesia, Fakultas Sastra, Universitas Pamulang ${ }^{1,2,3}$ Maillex51@gmail.com
}

\begin{abstract}
ABSTRAK
Media Sosial merupakan sebuah wadah daring yang memungkinkan setiap individu bisa melakukan komunikasi jarak jauh.dengan adanya sarana tersebut maka sangat mungkin terdapat terjadinya campur kode dan alih kode pada penggunaan bahasanya. Penelitian ini membahas mengenai terjadinya campur kode dan alih kode pada platform media sosial Twitter. Platform Twitter dipilih karena merupakan salah satu platform 10 teratas yang penggunanya paling banyak di Indonesia dan untuk pencarian data yang lebih efisien peneliti menggunakan fitur hastag pada Twitter. Tujuan penelitian ini untuk menganalisis sebuah fenomena campur kode dan alih kode yang dilakukan para pegiat pada platform media sosial Twitter. Untuk metode yang digunakan adalah metode kualitatif yang menekankan pada pengamatan fenomena dan lebih meneliti ke subtansi makna dari fenomena tersebut. Analisis penelitian ini dipengaruh pada kekuatan kata dan kalimat yang digunakan. Adapun teori yang digunakan sebagai landasan Campur kode dan Alih kode. Campur kode adalah penggunaan satuan bahasa dari satu bahasa ke bahasa lain untuk memperluas gaya bahasa atau ragam bahasa. Alih kode Menurut Appel (1976:79) gejala peralihan pemakaian bahasa karena berubahnya situasi. Untuk teknik pengumpulan data peneliti melakukan pengamatan kepada beberapa hastag yang sering masuk trending lalu dan mengambilnya dengan cara tangkap layar. Cara ini digunakan agar kemurnian data yang diambil terjaga tanpa ada coretan yang membuat datanya terlihat telah dimanipulasi. Untuk data hasil penelitian berupa frasa, kata, atau kalimat yang terdapat dalam media sosial Twitter dengan menggunakan metode kualitatif. Hasil penelitian ini menunjukkan bahwa para pegiat Twitter sering terjadi campur kode dan alih kode antar bahasa daerah, bahasa asing dan bahasa Indonesia.
\end{abstract}

Kata Kunci: Alih Kode, Campur Kode, Twitter

\section{PENDAHULUAN}

Bahasa berperan penting dalam kegiatan komunikasi dan interaksi sesama manusia sebagai makhluk sosial. Bahasa juga dapat menjadi identitas dalam kelompok masyarakat. Pada dasarnya kegiatan interaksi dan komunikasi harus berjalan baik dan benar, sehingga para pelaku komunikasi dapat saling memahami makna atau arti yang dilontarkan antar pelaku komunikasi. Menurut Kridalaksana (2008: 24) bahasa adalah sistem lambang bunyi yang bersifat arbitrer yang digunakan oleh suatu masyarakat untuk bekerjasama, berinteraksi, dan mengidentifikasi diri.

Bahasa yang digunakan oleh masyarakat Indonesia yaitu bahas Indonesia sendiri dan bahasa daerah sebagai bahasa Ibu mereka. Bagi kelompok masyarakat yang tinggal didaerah pedesaan yang memiliki kebudayaan yang sangat kental, bahasa daerah menjadi bahasa Ibu mereka dan bahasa Indonesia atau bahasa dari bangsa asing menjadi bahasa keduanya. Sedangkan, bagi kelompok masyarakat yang tinggal di perkotaan besar seperti Jakarta, yang kebudayaannya sudah agak pudar dan terkontaminasi oleh kebudayaan luar. Sehingga, bahasa Indonesia menjadi bahasa Ibu mereka dan bahasa asing menjadi bahasa keduanya. Terdapat sebutan bagi mereka yang mampu menguasai dua bahasa atau lebih yaitu dwibahasa, karena kelompok masyarakat tersebut memiliki keterbukaan dengan kelompok masyarakat lain.

Faktor terjadinya masyarakat dwibahasa atau bilingual yaitu karena kelompok masyarakat yang terbuka dengan kelompok masyarakat lain, seperti migrasi, urbanisasi, atau transmigrasi sehingga terjadinya keanekabahasaan. Kelompok masyarakat yang bermigrasi ke daerah lain, tentunya tidak akan berguna bahasa Ibu mereka. Sehingga mengharuskan mereka untuk mempelajari bahasa yang berlaku di daerah tersebut. 
Kemudian dari faktor pendidikan juga mengharuskan untuk memahami dua bahasa atau lebih. Dalam instansi pendidikan seperti sekolah, anak-anak juga diajarkan untuk mempelajari bahasa lain.

Apabila dalam kelompok masyarakat terdapat peralihan bahasa ke bahasa lain, maka peristiwa yang terjadi disebut alih kode. Tetapi jika dalam kelompok masyarakat terjadi peristiwa tutur yang menggunakan klausa maupun frasa campuran, dan masing-masing klausa atau frasa tidak lagi mendukung fungsi-fungsi sendiri, maka peristiwa yang terjadi disebut campur kode, bukan alih kode. Menurut Hymes dalam Chaer (2010: 107) alih kode itu bukan hanya terjadi antarbahasa, tetapi dapat juga terjadi antara ragam-ragam atau gaya-gaya yang terdapat dalam satu bahasa. Menurut Chaer (2010:114) alih kode dan campur kode adalah penggunaan dua bahasa atau lebih, atau dua varian dari sebuah bahasa dalam satu masyarakat tutur.

Fenomena alih kode dan campur kode banyak ditemukan dalam media sosial. Para pegiat media sosial kerap menggunakannya sebagai cara mereka menyesuaikan diri dalam berkomunikasi di media sosial. Di Indonesia sendiri, pegiat Twitter sangatlah banyak dan diminati. Hampir semua kalangan seperti orang dewasa, pelajar, bahkan selebriti menggunakan Twitter sebagai sarana berkomunikasi, mengungkapkan ekspresi, dan mencari informasi. Namun mayoritas pegiatnya terdiri dari kalangan remaja yang tidak buta akan kemajuan teknologi.

Tujuan dari penelitian ini untuk mengidentifikasi fenomena alih kode dan campur kode yang berada media sosial Twitter. Penelitian ini mencari faktor penyebab fenomena itu terjadi serta menganalisis tujuan dari subjek dalam melakukan hal tersebut.

Penelitian ini dapat bermanfaat sebagai penambah wawasan kebahasaan serta bisa dijadikan refresnsi bagi penelitian lain yang sejenis. Penelitian ini juga merupakan bentuk dari pelestarian bahasa yang timbul karena luasnya ruang orang-orang dalam berkomunikasi.

\section{LANDASAN TEORI}

Sosiolinguistik adalah cabang ilmu bahasa yang mempelajari hubungan antara bahasa dan faktorfaktor kemasyarakatan. Pengertian sosiolinguistik, jika dipandang dari segi etimologi merupakan gabungan antara kata sosiologi dan linguistik. Menurut Harimurti Kridalaksana (1978: 94) menjelaskan sosiolinguistik adalah ilmu yang mempelajari ciri dari berbagai variasi berbahasa, serta hubungan di antara para bahasawan dengan variasi bahasa tersebut di dalam suatu kelompok masyarakat. Sosiolinguistik merupakan kajian yang membahas tentang hubungan antara bahasa dengan pemakaiannya di masyarakat. Terdapat tiga macam tugas yang dimiliki sosiolinguistik, yaitu (1) menggambarkan sistem status sosial dan tingkat sosial hubungannya dengan kebiasaan berbicara dalam masyarakat, (2) membantu seseorang meningkatkan status sosialnya melalui pemakaian bahasa dan menemukan solusi dalam masalah kedwibahasaan yang ada di dalam kelompok masyarakat, (3) meneliti fenomena dialek di dalam masyarakat dwibahasa hubungannya dengan perubahan dan perkembangan bahasanya.

Campur kode adalah penggunaan satuan bahasa dari satu bahasa ke bahasa lain untuk memperluas gaya bahasa atau ragam bahasa, termasuk di dalamnya pemakaian kata, klausa, idiom, sapaan, dan sebagainya. Campur kode juga dapat dikatakan sebagai penggunaan serpihan dari bahasa asing, seperti bahasa Inggris, bahasa Arab, dan bahasa daerah. Fasold dalam Chaer (2004:115) menawarkan kriteria gramatika untuk 
membedakan campur kode dan alih kode. Jika seseorang menggunakan satu kata atau frasa dari suatu bahasa, dia telah melakukan campur kode. Tetapi apabila satu klausa jelas-jelas memiliki struktur gramatika satu bahasa dan klausa berikutnya yang disusun menurut gramatika bahasa lain, maka peristiwa tersebut dikatakan alih kode. Menurut Chaer (2010: 40) campur kode adalah sebuah kode utama atau kode dasar yang digunakan dan memiliki fungsi dan keotonomiannya.

Alih kode merupakan suatu fenomena kebahasaan yang bersifat sosiolinguistik dan merupakan gejala umum yang terjadi dalam kelompok masyarakat bilingual atau dwibahasa. Menurut Suwito (dalam Aslinda dan Syafyahya, 2007: 86) alih kode terdapat dua macam, yaitu alih kode internal dan ekternal. Alih kode internal terjadi antar bahasa sendiri seperti bahasa daerah dengan bahasa Indonesia, sedangkan alih kode eksternal adalah terjadi antara bahasa Indonesia dengan bahasa asing, seperti bahasa Inggris, bahasa Arab, dan bahasa lain.

\section{METODE}

Jenis penelitian ini adalah kualitatif deskriptif. Metode kualitatif deskriptif digunakan sebagai cara peneliti meneliti bagaimana alih kode dan campur kode ini terjadi pada twet para pengguna Twitter di setiap tagar yang trending. Untuk pengumpulan data peneliti melakukan penelusuran pada setiap percakapan yang menggunakan tagar tersebut dan melakukan tangkap layar.

\section{HASIL PEMBAHASAN}

1. Campur Kode

Campur Kode didefinisikan sebagai pristiwa yang dimana penutur menyisipkan kode lain yang berada diluar bahasa ibunya. Campur kode ini bisa disebabkan karena menyesuaikan dengan topik pembicaraan atau situasi informal yang mendukungnya.

\section{Data 1}
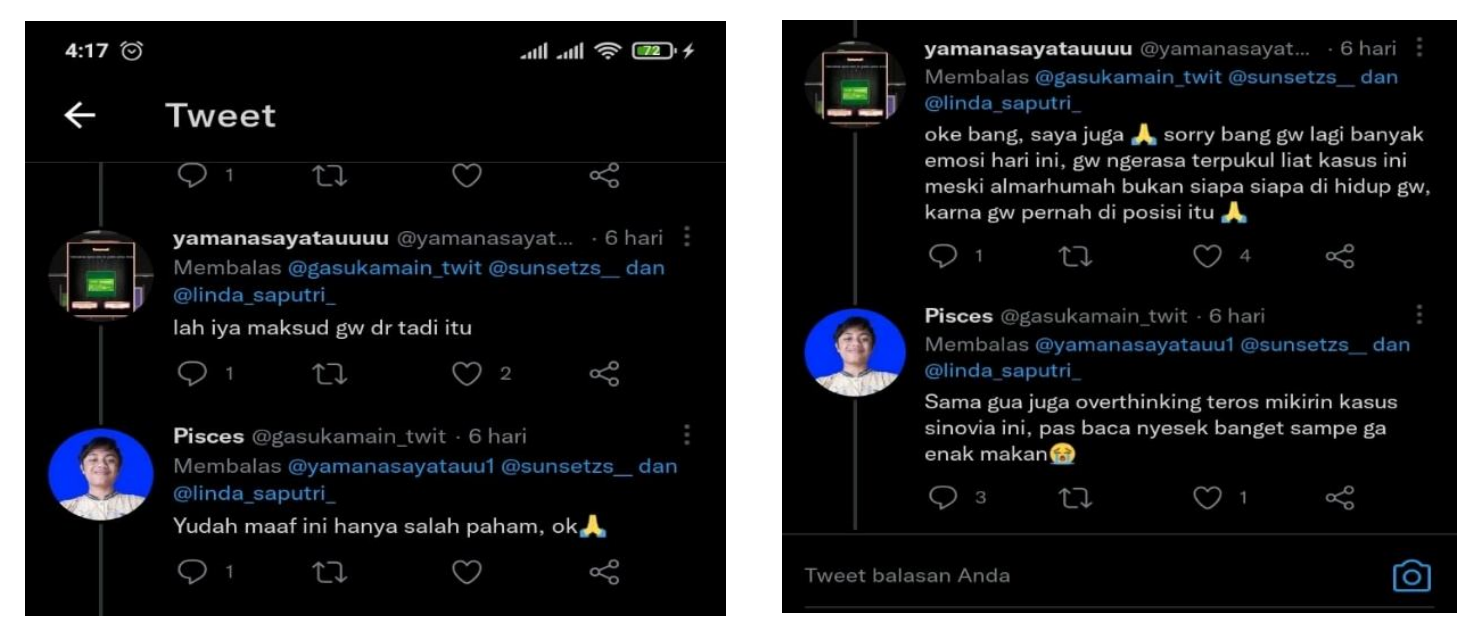
1. Lah iya maksud gw dari tadi itu

2. Ya udah maaf ini hanya salah paham, oke

5. Oke bang, saya juga sorry bang gw lagi banyak emosi hari ini, gw ngerasa terpukul liat kasus ini meski almarhumah bukan siapa siapa dihidup gw, karena gw pernah di posisi itu

6. Sama gua juga overthinking terus mikirin kasus sinovia ini, pas baca nyesek banget sampe gak enak makan

Pada percakapan di atas antara tokoh 1 dengan tokoh 2. Pertama mereka menggunakan bahasa Indonesia yang dapat diketahui sebagai bahasa Ibu mereka. Kedua pada saat percakapan terus dilanjutkan, tokoh 1 dan tokoh 2 saling meminta maaf dengan menyisipkan kata dalam bahasa Inggris seperti oke, sorry, dan overthinking.

Jenis campur kode tersebut adalah campur kode kedalam (innercode mixing). Karena bahasa Ibu dari kedua tokoh tersebut adalah bahasa Indonesia dan menyisipi kata dari bahasa asing yaitu bahasa Inggris. Saat menyisipkan kata dalam bahasa Inggris kedua tokoh tersebut saling memahami maksud atau arti dari kata yang dituturkannya masing-masing. Sehingga diantara mereka tidak terjadi kesalahpahaman dan peristiwa pertuturan atau interaksi dapat dilakukan secara efektif.

Data atau kasus tersebut saya temukan dalam twitter yang bertagar '\#percumalaporpolisi'. Tagar tersebut sempat viral dalam dunia maya dikarenakan salah satu anggota polisi yang bernama Randy, memperkosa salah seorang perempuan bernama Novia Widyasari, yang kemudian perempuan itu berakhir dengan bunuh diri karena tekanan yang didapatnya dari orang lain.

\section{Data 2}
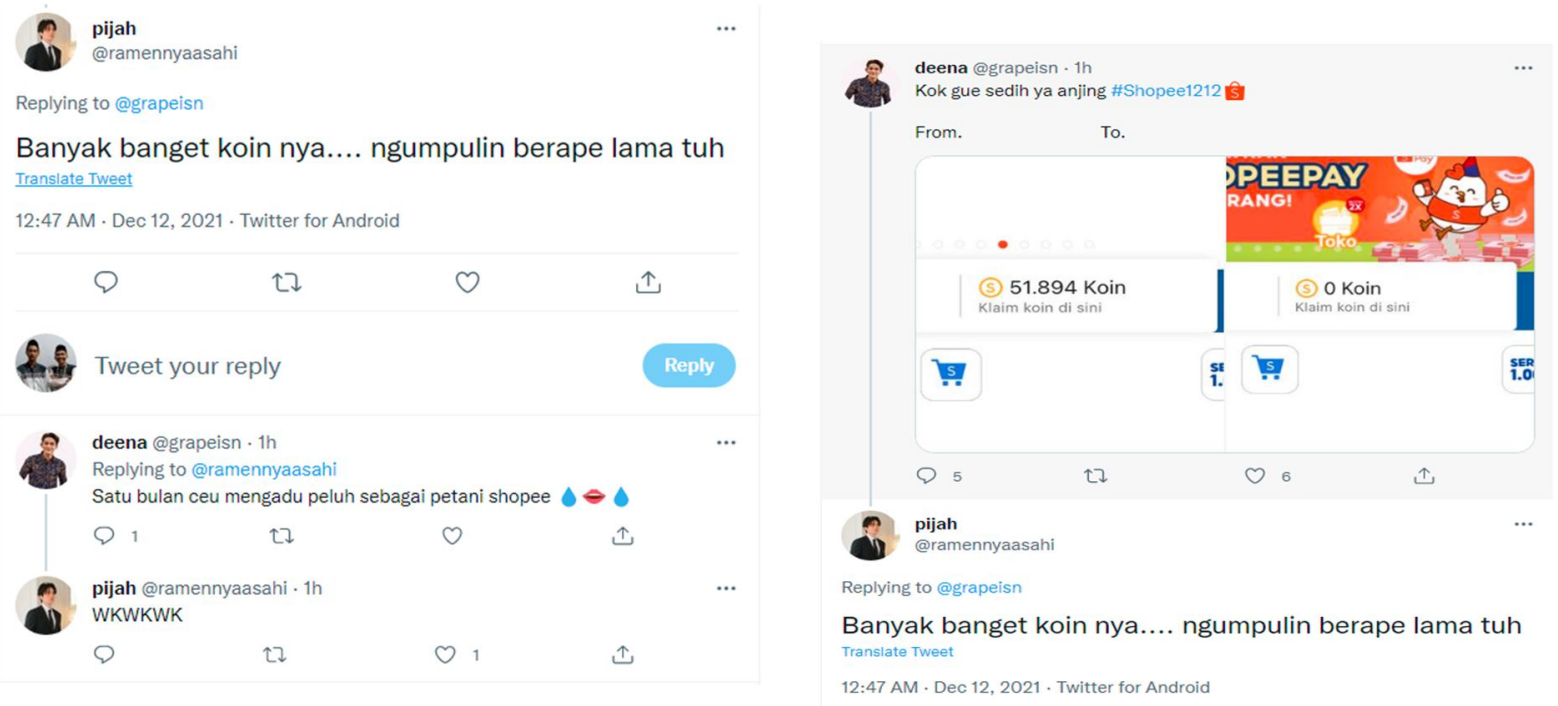
Peristiwa alih kode dapat terlihat pada percakapan tersebut.

1. Kok gue sedih ya anjing \#shopee1212

2. Banyak banget koinnya.... Ngumpulinnya berapa lama tuh?

1. Satu bulan $с е и$ mengadu peluh sebagai petani shopee

\section{WKWK}

Pada percakapan di atas antara toko 1 dan 2. Pertama mereka menggunakan bahasa Indonesia sebagai bahasa yang diketahui sebagai bahasa Ibu mereka. Kedua percakapan tersebut terus dilanjutkan, tokoh 1 menjawab pertanyaan dari tokoh kedua dengan menyisipkan kata $\mathrm{Ceu}$ yang merupakan bahasa Sunda.

Jenis campur kode tersebut adalah campur kode internal. Karena bahasa ibu dari kedua tokoh tersebut adalah bahasa Indonesia dan menyisipkan kata dalam bahasa Daerah yaitu bahasa Sunda. Saat menyisipkan kata dalam bahasa Sunda kedua tokoh tersebut saling memahami maksud atau arti dari kata yang dituturkan keduanya sehingga interaksi keduanya tidak menimbulkan kesalahpahaman dan peristiwa pertuturan atau interaksi dapat dilakukan secara efektif.

Data kasus tersebut saya temukan pada media sosial Twitter yang bertagar '\#shopee1212'. Tagar tersebut sedang viral karena event 12.12 adalah salah satu event diskon yang di mana pada event tersebut banyak brand yang mengadakan diskon besar-besaran. 
2. Alih Kode

Alih Kode diartikan sebagai fenomena linguistik yang dimana penutur melakukan peralihan dari bahasa ibu ke ragam lain dari bahasa tersebut, atau juga ke bahasa asing.

\section{Data 3}
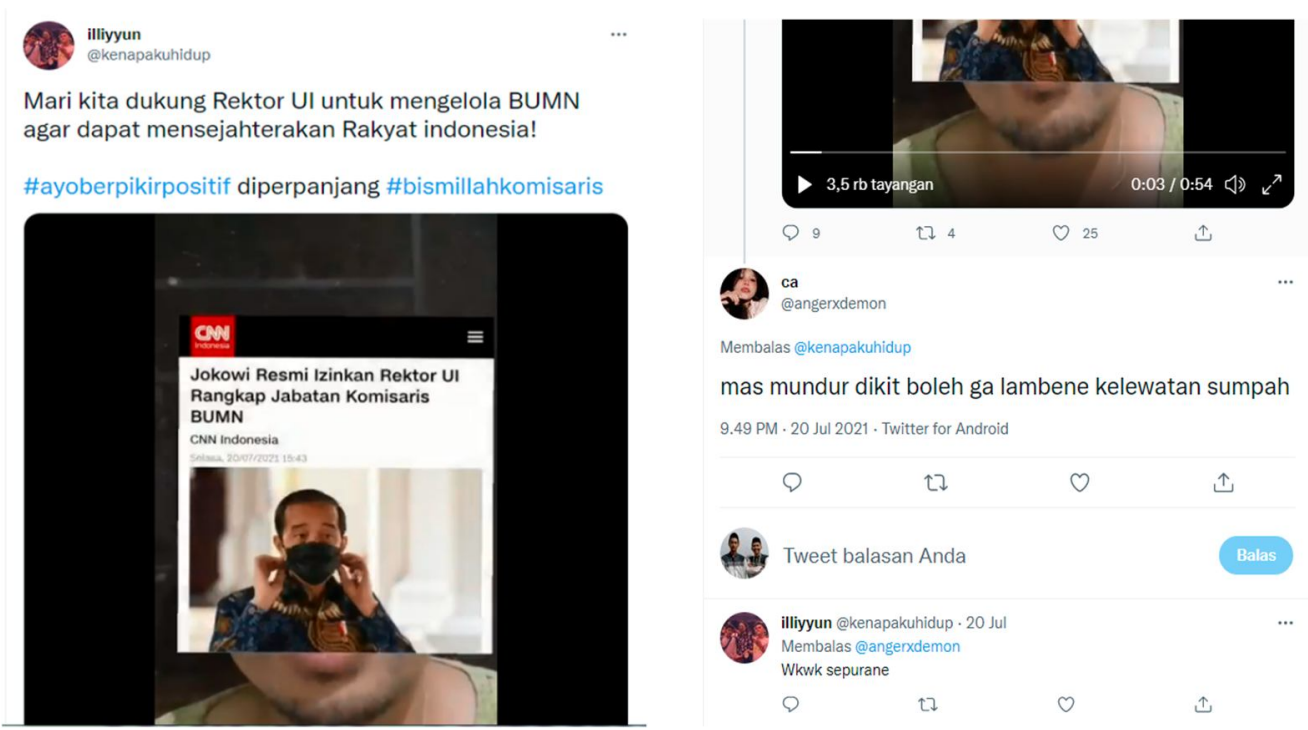

mas mundur dikit boleh ga lambene kelewatan sumpah 9.49 PM 20 Jul 2021 - Twitter for Android

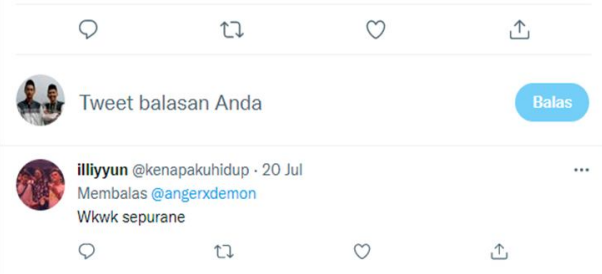

Peristiwa alih kode dapat dilihat dari percakapan tersebut.

1. Mari kita dukung Rektor UI untuk mengelola BUMN agar dapat mensejahterakan Rakyat Indonesia!

\#ayoberpikirpositif diperpanjang \#bismillahkomisaris

2. Mas mundur dikit boleh gak lambene kelewatan sumpah

1. Wkwk sepurane

Pada percakapan di atas antara tokoh 1 dengan tokoh 2. Tokoh 1 yang awalnya menyatakan ajakan dan dukungan kepada Rektor UI untuk mengelola BUMN agar rakyat Indonesia sejahtera, kemudian dibalas oleh tokoh 2 yang mempermasalahkan wajah atau mulutnya yang kelewatan. Sehingga tokoh 1 dan tokoh 2 pun mengalihkan pembahasannya kepada wajah atau mulutnya yang kelewatan.

Dari data di atas dapat kita nilai bahwa percakapan tersebut merupakan peristiwa alih kode, yang awalnya membahas Rektor UI dalam mengelola BUMN menjadi mempermasalahkan wajah atau mulut dari tokoh tersebut. Peristiwa terjadinya alih kode dimulai oleh tokoh 2 yang mempermasalahkan wajah atau mulut yang tidak ada hubungannya dengan pernyataan awal. Jenis alih kode tersebut adalah alih kode intern yang terjadi pada saat menggunakan bahasa Indonesia ke dalam bahasa daerah. Dari peristiwa di atas ke dalam bahasa Jawa, yaitu lambene dan sepurane. 
Data atau kasus tersebut saya temukan dalam twitter yang bertagar '\#ayoberpikirpositif' dan '\#bismillahkomisaris'. Tagar tersebut sempat viral dalam dunia maya dikarenakan salah satu petinggi dari instansi pendidikan yaitu Rektor UI yang merangkap menjadi komisaris BUMN dan petinggi universitas.

\section{KESIMPULAN}

Berdasarkan pemabahasan di atas dapat disumpulkan bahwa proses terjadinya alih kode dan campur kode ini didasarkan keinginan penutur dalam membangun suasana ataupun menyesuaikan pokok pembicaraan. Seperti yang ada pada data pertama, dimana penutur dan mitra tutur mnyisipkan bahasa asing agar percakapan tidak kaku dan layaknya berbicara dengan teman dekat. Pada data ketiga penutur melakukan alihkode didasari penyesuaian dengan mitra tutur yang menjawab dengan ragam bahasa lain. dengan kata lain alih kode dan campur kode yang terjadi di Twitter ini, bertujuan untuk menjalin keakraban dengan orang asing.

\section{DAFTAR PUSTAKA}

Agutinuraida, Ida. (2017). Alih Kode dan Campur Kode dalam Tuturan Bahasa Indonesia oleh Mahasiswa Prodi Pendidikan Bahasa Indonesia Universitas Galuh Ciamis. Ciamis: Universitas Galuh.

Chaer, Abdul. (2014). Linguistik Umum (Ed.Rev). Jakarta: Rineka Cipta.

Haryono, Akhmad. (2012). Perubahan dan Perkembangan Bahasa: Tinjauan Historis dan Sosiolinguistik. Tegalboto: Universitas Jember.

Mustikawati, Diyah Atiek. (2015). Alih Kode dan Campur Kode antara Penjual dan Pembeli (Analisis Pembelajaran Berbahasa Melalui Studi Sosiolinguistik). Ponorogo: Universitas Muhammadiyah Ponorogo.

Pribadi, Narindra Ramadhani. (2020). Kajian Sosiolinguistik: Alih Kode dan Campur Kode dalam Video Youtube Gita Savitri Devi. Surakarta: Universitas Sebelas Maret.

Susmita, Nelvia. (2015). Alih Kode dan Campur Kode dalam Pembelajaran Bahasa Indonesia di SMP Negeri 12 Kerinci. Jambi: STKIP Muhammadiyah.

Wijana, I Dewa Putu. (2021). Pengantar Sosiolinguistik. Yogyakarta: Universitas Gadjah Mada.

Yuliani, Wiwin. (2018). Metode Penelitian Deskriptif Kualitatif Dalam Perspektif Bimbingan dan Konseling. Cimahi: IKIP Siliwangi. 